\title{
WAGE FLEXIBILITY, EXCHANGE-RATE COMPETITIVENESS AND FULL EMPLOYMENT: THE FIRST HERETICS
}

\author{
Julio López G. ${ }^{a}$ \\ ${ }^{a}$ Retired Professor from Universidad Nacional Autónoma de México. Mexico City, Mexico. ORCID: \\ https://orcid.org/0000-0003-3798-4771.
}

Received on 11 February 2019

Accepted on 28 May 2019

\begin{abstract}
This paper discusses Keynes' and Kalecki's rejection of the notion that downward wage flexibility would ensure full employment, recollecting also Steindl's stagnation theory, which extends to the long-run Kalecki's ideas. It then considers the association between wage fall and currency depreciation and examines the Latin American contribution to the arguments of why currency devaluation may depress aggregate demand. Afterwards, it briefly reflects on the economic policy consequences that the authors studied here inferred from their analysis. It finally adds a succinct remark on the author's empirical findings on this issue.
\end{abstract}

KEYWORDS: distribution; growth; wages; exchange rate; Kaleckian economics; Keynesian economics; Latin America.

JEL CODES: E11; E12; B12; O1. 


\section{FLEXIBILIDADE SALARIAL, COMPETITIVIDADE CAMBIAL E PLENO EMPREGO: OS PRIMEIROS HEREGES}

RESUMO: Este artigo discute a rejeição de Keynes e Kalecki à noção de que a flexibilidade do salário para baixo asseguraria o pleno emprego, recordando também a teoria da estagnação de Steindl, que se estende às ideias de Kalecki de longo prazo. Em seguida, o artigo considera a associação entre queda salarial e depreciação cambial e examina a contribuição latino-americana para os argumentos de porque a desvalorização da moeda pode deprimir a demanda agregada. Posteriormente, reflete brevemente sobre as consequências da política econômica que os autores estudados aqui inferiram de suas análises. Por fim, acrescenta uma observação sucinta sobre as descobertas empíricas do autor sobre essa questão.

PALAVRAS-CHAVE: distribuição; crescimento; salários; taxa de câmbio; Kalecki; Keynes; América Latina. 


\section{INTRODUCTION*1,2}

An important debate has been taking place among researchers inspired by Keynes's and Kalecki's ideas, which is about the effects of wage variations on demand and employment. This debate has stimulated much theoretical thinking and many pages of empirical research and has greatly enriched our understanding of the topics involved. In this paper, I will carry out an exegesis of the thoughts of Keynes and Kalecki - the two founding fathers of the principle of effective demand - on that topic, as well as of other relevant authors who have discussed it. My own contribution to the debate will be modest because above all I will let those authors speak by themselves.

With this objective in mind, first of all, I will review how Keynes and Kalecki rejected the (neo)classical notion that downward wage flexibility would safeguard full employment, with the latter author arguing that such a fall will more likely deepen unemployment. Then I will recollect how Steindl showed that the negative impact on demand and employment of a wage decline anticipated by Kalecki might carry over to the long run, engendering a stagnation tendency. A second issue I will take up is the extension of the debate to the open economy. Here I will discuss the association between wage fall and currency depreciation and will bring to light the Latin American contribution to the discussion of why a devaluation may depress aggregate demand. Afterwards I will briefly discuss the economic policy consequences that the authors considered here inferred from their analysis. As a Coda, I will add a succinct remark on my empirical findings on this issue.

\section{THE CLOSED-ECONOMY STORY}

First of all, let us examine how Keynes and Kalecki, the founding fathers of the principle of effective demand, discussed the profit-led and wage-led demand regimes. I will also

* Note from the Editors: Mr. López Gallardo passed away a year after this paper had been accepted for publication, but before he could approve the pdf file for this special issue in honor of Fernando Cardim de Carvalho, his old colleague. We thank Mr. López Gallardo's family for allowing the publication of this paper. It is a way of honoring them both. We also thank Verónica De Jesus Romo - one of Mr. López Gallardo's last Ph.D. pupils and a professor/researcher at the Juarez Autonomous University of Tabasco (UJAT), México - for proofreading this pdf for publication.

1 In the course of writing a joint paper (CARVALHO and LÓPEZ, 2019), Fernando and I discussed a lot on the issue I am taking up here, and we envisioned the possibility of a joint paper on the matter. It is very sad that ultimately I have to write the present paper on my own.

2 I would like to thank Tony Thirlwall, Gary Dimsky, Gerardo Fujii, Luis Daniel Torres, Moritz Cruz, and Sebastien Charles for their comments to a previous version of this paper. 
include a brief comment on Steindl's work because this author made an important contribution to the debate on demand regimes. ${ }^{3}$

It is well known that a reduction of wages plays a key role in the conventional story regarding the alleged property of capitalist economies to ensure full employment. In the classical and neoclassical views, if actual output declines below potential output and thus unemployment arises, then wages and prices will fall. That fall will, in turn, raise the potential profitability of additional production, even if it stimulates demand. In the original closed-economy version of the story, the demand stimulus comes from two effects. One is the so-called 'Keynes effect', namely the inducement to investment brought about by a reduction in interest rates. This effect, of course, would come about under anexogenous view of money, where it is assumed that the nominal amount of money is given and that demand for money falls when prices decline. The second effect, the 'Pigou effect' (or the 'real balance effect'), also pertaining to the closedeconomy case, comes from the notion that with lower prices savers will feel richer and consume a larger proportion of their current income.

In his critique of this (neo)classical proposition, Keynes argued in The General Theory (1964, p. 262) that there is no way of knowing whether wage cuts will reduce unemployment without learning their effect on the components of aggregate demand - consumption, investment and the foreign balance. Anyway, he firstly assumed, for expository purposes, a given nominal wage, but in chapter 19 of this work he discussed the consequences of wages falling with unemployment. Unfortunately, following the interpretation of the message of The General Theory encapsulated in Hicks's (1937) model, in a great part of the subsequent literature Keynes's outlook was reduced to a single idea: the 'liquidity trap.'

Of course, Keynes had this possibility in mind, which anyway he considered to be a 'limiting case." To this limiting case, Keynes added several obstacles to the conventional full-employment mechanism, of which I only mention here a few. One was the notion that the real amount of money might not rise as a consequence of the

3 Another heterodox economist, Richard Goodwin has been mentioned in the discussion about demand regimes sometimes (BARBOSA FILHO and TAYLOR, 2006). He proposed a classical model based on the predator-prey system, where wage flexibility gives rise to cycles rather than full employment (GOODWIN, 1967). However, in my view, he is an 'outlier' in this debate. As he himself later recollected (PALAZZI, 1982, p. 40), "[w] hen I discussed for the first time my 1967 paper in a seminar at Cambridge, Joan Robinson (...) dismissed my work(...) She said (...) that my argument was pre-Keynesian, for the basic hypothesis was ultimately that of full employment" (I thank Prof. Gugliemo Chiodi for this reference and the English translation of the paragraph). Surely Goodwin's model has many merits, but I share Robinson's remark that in it the problem of effective demand is entirely lacking.

4 He added, "I know of no example of it hitherto" (KEYNES, 1964, p. 207, my emphasis). 
wage and price decrease. Thus, to express the point with the conception of endogenous money approach he put forward in his Treatise on Money (KEYNES, 1930), he stated:

[i]t is, therefore, on the effect of a falling wage- and price-level on the demand for money that those who believe in the self-adjusting quality of the economic system must rest the weight of their argument; though I am not aware that they have done so. ${ }^{5}$ If the quantity of money is itself a function of the wage- and price-level, there is indeed, nothing to hope in this direction. (KEYNES, 1964, p. 266)

Besides that, he discussed the issue taking into consideration expectations, by arguing that: "[i]f (...) the [wage] reduction leads to the expectation, or even to the serious possibility, of a further wage reduction in prospect, (...) [it] will diminish the marginal efficiency of capital and will to a postponement of both investment and of consumption" (KEYNES, 1964, p. 263). And he went on: “[i]f, moreover, the reduction in wages disturbs political confidence by causing popular discontent, the increase in liquidity preference due to this cause may more than offset the release of cash from the active circulation" (KEYNES, 1964, p. 263-264).

He added the important argument that falling prices would raise the burden of the debt and this might discourage investment:

the depressing influence on entrepreneurs of their greater burden of debt may partially offset any cheerful reactions from the reductions of wages. Indeed if the fall of wages and prices goes far, the embarrassment of those entrepreneurs who are heavily indebted may soon reach the point of insolvency--with severe adverse effects on investment. (KEYNES, 1964, p. 264)

I recollect here this idea because it is especially significant in the present stage of highly 'financialized' capitalism. We know that Minsky $(1975,1986)$, one of Keynes's most innovative followers, gave special relevance to the indebtedness ratio of firms in his explanation of instability of capitalist economies.

Kalecki went further than Keynes in his critique of the conventional view, arguing that a wage fall may in fact increase unemployment. To explain his standpoint, it is useful to start with the following three equations that encapsulate his theory (KALECKI, 1971):

$$
P=I+C^{K}+\beta+T
$$

\footnotetext{
5 Since he could not read Polish, he could not have known Kalecki's (1934) paper cited below.
} 
Equation (1) comes from the basic National Accounts identity, if it is assumed that workers' savings as well as overheads are nil, and that all workers are productive workers. $P$ represents total gross profits; $I$ is private investment; $C^{K}$ is the capitalist consumption, while $\beta$ is the budget deficit; and $T$ refers to the trade balance (exports minus imports).

Equation (1) being an accounting identity, it is always valid. Kalecki, however, makes it a theory on the basis of three assumptions, which imply that in (1) causality runs from right to left in the equation (LÓPEZ and ASSOUS, 2010). First, firms adjust their production to the volume of sales with no lags; in other words, only what is sold is produced. Second, idle capacity is pervasive. Third, decisions regarding capitalists' expenditure on consumption or investment are taken after a certain delay, and they are unlikely to change in any given short period. All this means that in any given short period, it is expenditure that determines output and profits and not the other way around.

The second equation, Kalecki's distribution of income theory, is:

$$
\omega=\frac{1}{1+(k-1)(j+1)} ; \quad k>1
$$

This equation shows that the relative share of wages in value added $\omega$ is determined by two variables: $k$ and $j{ }^{6}$ Here, $k$ is what Kalecki called 'degree of monopoly', expressed as the ratio of average price to average direct cost; ${ }^{7}$ while $j$ is equal to the ratio of total costs of materials to total wages paid. Again, this is an accounting identity, which Kalecki turned into a theory by stating that firms fix their prices by adding a mark-up to their variable costs, which he assumed to be constant in the short run.

Finally, equation (3) indicates that total output $Y$ depends on total profits and the share of profits in output.

$$
Y=\frac{I+C^{K}+\beta+T}{(1-\omega)}
$$

To simplify the discussion, let us first consider a closed economy without government $(T=\beta=0)$ and where all costs are labor costs. Suppose that wages decline; since capitalist spending does not automatically rise, profits will remain

6 Kalecki also included the output mix among determinants of the wage share, which I here omit to simplify matters.

7 An algebric relation exists between the concepts of degree of monopoly, profit margin, and mark-up. Here I use the three terms indistinctly, because they have an exact, positive association. 
constant. If prices fall at the same rate as labor costs do, the degree of monopoly does not change, and workers' consumption in real terms is also constant. Thus, aggregate demand (and hence output) is constant. Nothing has changed except that prices are lower, and unemployment has not been absorbed. However, Kalecki argued, "most likely some prices will prove to be 'rigid' and thus will fail to decline in the same proportion as wages" (KALECKI, 1939b, p. 36). Therefore, the degree of monopoly or the ratio of total costs of materials to total wages, or both - rise, but total profits do not. Since $\omega$ declines, workers' consumption falls, dragging with it effective demand and employment (see equation 3). Until the end of his life, Kalecki (1971) though this second case to be the most likely one and therefore considered that a wage fall would entail lower demand and employment.

Interestingly, Kalecki knew that the price fall might bring about a reduction in the short-term interest rate, which could later on encourage investment. In fact, he was the first, to my knowledge, to propose in print what later came to be known as 'the Keynes effect' (KALECKI, 1934). ${ }^{8}$ However, he definitely considered this effect to be of secondary importance, adding that falling prices might rather cause a recession. In a paragraph where he anticipated his celebrated rebuttal to Pigou (KALECKI, 1944b), he wrote,

as a consequence of the decrease of the general price level with unchanged level of production, the demand for cash diminishes and this in turn causes (...) a decrease of the short-term rate of interest, which may favourably affect investment (...) However (...) changes in the short-term rate influence but slightly the long-term rate which is relevant to investment (...) It may even be argued that the opposite is often the case. A general reduction of prices increases the burden of indebtedness, since money incomes diminish while the 'old' debts do not. This causes difficulties in servicing the debts, ending frequently in failures. As a result, confidence in the solvency of firms is undermined, which may lead to an increase in the long-term rate of interest even though the short-term rate declines. (KALECKI, 1939b, p. 30)

It is as well to recall that, on the issue under discussion, Keynes and Kalecki had important differences. Though Keynes did not accept the view that a wage fall would raise demand and employment, in The General Theory he argued that higher

\footnotetext{
8 The paper was originally published in Polish and was not translated into English until the publication of the first volume of the Collected Works of Michal Kalecki, in 1990. By the way, Kalecki showed in that paper that even under strict '(neo)classical' assumptions, the wage fall might not ensure full-employment unless wages responded in a very particular way to unemployment.
} 
employment would result in lower real wages because the marginal productivity of labor would decline. ${ }^{9}$

In contrast, Michal Kalecki rejected the hypothesis of decreasing marginal productivity of labor. He assumed rather that unit costs would be constant within a relatively ample margin of output. Moreover, real wages were not set by labor productivity but depended on the bargaining power of workers. His socialist outlook is strongly encapsulated in the following sentence:

There are certain "workers' friends" who try to persuade the working class to abandon the fight for wages, of course in its own interest. The usual argument used for this purpose is that the increase of wages causes unemployment, and is thus detrimental to the working class as a whole (...) Our investigation (...) has shown that a wage increase (...) tends to reduce the degree of monopoly and thus to raise real wages (...) If viewed from this standpoint, strikes must have the full sympathy of "workers' friends". For a rise in wages tends to reduce the degree of monopoly, and thus to bring our imperfect system nearer to the ideal of free competition. (KALECKI, 1939a, p. 284)

It may be useful to open here a brief digression, which may be interesting especially for Latin American readers. The notion that low wages encourage growth reappeared in the 1950s in the field of development economics, stimulated by A. W. Lewis's (1954) work. As readers may recall, this author proposed a 'classical' model of a dual economy in which a modern (industrial) sector coexists with a backward (agricultural) sector where disguised unemployment is pervasive. Industrial marginal labor productivity is decreasing but is higher than productivity in agriculture. Real industrial wages depend on and are set at a higher level than the subsistence wage of agricultural workers. At that wage level, industrial firms can employ as many people as they want, and they will hire workers up to the point where their real wage equals industrial productivity. Low real wages entail high industrial profits, and all profits are automatically reinvested. Thus, low wages stimulate demand and employment, with the implication that growth would normally be 'profit-led' in developing economies.

At about the same time than Lewis, Kalecki also wrote a paper on the subject (KALECKI, 1954). Though he considered that the main problem of underdeveloped economies is scarcity of capital and thus argued that without sufficient investments

9 Afterwards, and in the light of empirical evidence, Keynes recanted from his previous opinion (KEYNES, 1939). 
long-term growth could not be achieved, his view was entirely different from Lewis's. Kalecki stated that in the course of economic development there would be "a tendency of increased concentration in industry, a rise in the degree of monopoly may easily take place" (KALECKI, 1954, p. 32). He then asked: "[w] hat will be the repercussions of an increase in the degree of monopoly? The rise of prices in relation to wages will reduce effective demand and prevent the full utilization of industrial facilities" (Ibidem, emphasis added). Thus, in Kalecki's view, a higher profit share - brought about either by the fall of urban wages or by the rise of the degree of monopoly - will not necessarily translate into higher absolute profits. It may simply entail lower demand and lower utilization of productive capacities. Hence his (implicit) rejection for the claim that in developing economies growth would be profit-led.

Let us now come back to the main subject of this paper. I will recall now a work that, to my mind, has not received the attention it deserves in the debate on demand regimes. I refer to Steindl's "Maturity and stagnation in American capitalism" (STEINDL, 1952), which was an innovator on the issue under discussion. Indeed, in his magnum opus, Steindl was the first to discuss how in the US economy a wage-share decline would negatively affect the long-run growth process.

Steindl proposed his theory to account for what he saw as a secular stagnation tendency in the US economy once it had reached maturity. He postulated that, once this stage had been attained, the market share of large and gigantic firms would normally be very sizeable, and concomitantly the market share of medium-sized and small firms would decrease considerably. This would bring about two significant changes in the behavior of large firms. On the one hand, they would become more reluctant to carry out investments when what they consider excess surplus capacity emerges. On the other hand, price competition becomes less severe, such that gains in labor productivity thanks to technical progress result now in higher profit margins rather than lower prices. The reason in both cases is that efforts to eliminate excess capacity would require them to gain higher market shares. But that would be too costly now, because small, financially weak and easy-to-outcompete firms occupy a smallermarket share.

Steindl's argument for the long-run economic stagnation relies on an investmentdecision function where, to simplify, the rate of growth of investment depends positively on two variables: the rate of profit and the degree of capacity utilization (defined here as the ratio of effective output to capital equipment). To start with, he (implicitly) considered a private and closed economy, where private investment has been growing at a steady-state $\alpha$, and capitalist consumption is a constant share of profits, so that profits are also growing at the rate $\alpha$ (see equation 1 ). The wage share is constant, and thus aggregate demand is also growing at a rate $\alpha$ (equation 3 ). 
Capital, namely accumulated investment, also grows at a rate $\alpha$, and thus the profit rate and the degree of capacity utilization are constant.

He then introduced a distributional shock, arguing that under monopoly capitalism profit margins (Kalecki's degree of monopoly) tend to rise (see equation 2). In the short-term, overall profits and the profit rate do not rise but the rate of growth of demand declines below $\alpha$ (see equation 3 ). Therefore, the rate of capacity utilization decreases, which discourages investment that now grows at a rate $\eta<\alpha$. This entails a drop in the rate of growth of profits and in the profit rate. Correspondingly, the rate of growth of demand falls again, to $\lambda<\eta<\alpha$, the rate of growth of investment is further discouraged, and a stagnation tendency sets in. As we can see, Steindl considered growth to be wage-led, and he was probably the first one to show how a short-run negative shock to the wage-share carries over to the long-run.

\section{AN EXTENSION OF THE ANALYSIS: THE WAGE SHARE, THE EXCHANGE RATE, AND EFFECTIVE DEMAND}

Let us now turn our attention to an extension of the analysis, which has to do with the open-economy case and the role of the real exchange rate. This is the third channel that in neoclassical economics would bring about full employment in a capitalist economy. This effect is of more recent vintage and adds to the two previous effects (i.e. the 'Keynes effect' and the 'Pigou effect') the depreciation of the domestic currency and the enhanced competitiveness ensuing from the wage and price fall.

In this view, if actual output falls below potential output causing unemployment, workers' bargaining power will decline. Consequently, nominal wages fall entailing a fall in domestic prices. Therefore, for a given nominal exchange rate, the real exchange rate depreciates. ${ }^{10}$ It is usually supposed that the Marshal-Lerner condition holds, at least in the medium and long term. Accordingly, the wage fall stimulates a rise in net external demand, and the output gap, together with unemployment, is eliminated. Moreover, given the downward rigidity of nominal wages prevailing today, currency

${ }^{10}$ I define the real exchange rate $(q)$ here as $q=e\left(p^{*} / p\right)$ where e indicates the domestic currency nominal exchange rate vis-à-vis the foreign currency, while $p^{*}$ and $p$ indicate the foreign and domestic price indexes, respectively. Thus, competitiveness improves when the real exchange rate rises. Note that the real exchange rate does not vary if the economy is price-taker, such that $p=e p^{*}$. I exclude this case from the analysis because it is unrealistic. 
depreciation is frequently recommended to accelerate the process. This may entail a momentary price hike but would also bring about the requiredreal wages fall.

Let us see how Keynes and Kalecki envisioned the issue. In The General Theory, Keynes posited: "a reduction of money-wages (...) is likely to worsen the terms of trade. Thus there will be a reduction in real incomes, except in the case of the newly employed, which may tend to increase the propensity to consume" (KEYNES, 1964, p. 263). This paragraph is somewhat obscure, but I think it can be understood as follows: the worsening of the terms of trade will by itself reduce the purchasing power of the already employed workers, thus diminishing their demand. But this may be offset or more than offset if the trade balance improves because this brings about higher employment in the export and import-competing industries. If the latter effect is strong enough, total employment rises, also entailing a higher propensity to consume.

At a later date Keynes discussed the association between a wage fall and currency depreciation, as well as the consequences of the latter on demand. In his proposal for the post Second World War international financial organization, he wrote:

[T] here are two objections to movements in the rate of exchange (...). The first relates to the effect on the terms of trade (...) in certain conditions of the elasticities involved, a depreciation in the rate of exchange may actually worsen the balance of payments, (...). In the second place, in the modern world, where wages are closely linked with the cost of living, the efficacy of exchange depreciation may be considerably reduced. (KEYNES, 1980, p. 288)

Kalecki's discussion of the open-economy case was brief but has important implications. Note first that Kalecki made explicit the close association between a reduction of wages in an open economy and currency depreciation, arguing that

The two cases differ only in that in the former the wages decline and the prices of imported raw materials remain unchanged, while in the latter the wages remain unaltered (in terms of domestic currency), and the prices of imported raw materials increase in inverse proportion to the currency depreciation. (KALECKI, 1939b, p. 38)

He then concluded,

(...) even in such a case [i.e., in an open system], the reduction of wages does not necessarily lead to an increase in employment, and the prospects of raising the aggregate real income of the working class are even dimmer. In particular, under the system of high and rising tariffs, it is very likely that a reduction of wages will have an adverse effect on employment also in an open economy. (KALECKI, 1939b, p. 38) 
It is important here to go deeper into some open-economy consequences that follow Kalecki's profit equation (1) and his effective demand equation (3). Let us first of all consider the case when the Marshall-Lerner is not fulfilled, i.e. when a wage fall (and the consequent rise in the real exchange rate) does not improve the trade balance. ${ }^{11}$ Now, when this is the case, a wage fall may cause a fall in aggregate profits (and in the profit rate). Indeed, the wage fall depresses demand and output, which by itself triggers an improvement in the trade balance. But on the other hand, under the assumptions considered, the trade balance tends to deteriorate when the real exchange rate rises. If this latter effect is stronger than the former, the net effect on the trade balance is negative, and aggregate profits fall. Of course, this entails also a fall in aggregate demand and the degree of capacity utilization. In turn, the fall in profits and capacity utilization discourages investment, which brings about a stagnation tendency as per Steindl's theory.

Let us now consider the case when the Marshall-Lerner condition is fulfilled, and to simplify let us assume that Kalecki's degree of monopoly remains constant when the real wage falls and the real exchange rate rises. In this case, the wage fall by itself tends to improve the trade balance. But at the same time that fall entails a rise in the variable $j$, the ratio of raw materials to wage costs, because some of the raw materials are imported, and their prices do not fall. Now, even though the improvement in the trade balance tends to stimulate demand and output, on the other hand the rise in $j$ and the decline in the wage-share negatively affect aggregate demand, as per equation (3), as well as the degree of capacity utilization. Accordingly, even when the Marshall-Lerner condition is fulfilled, a wage fall may fail to stimulate higher output. The impact of that fall on the wage share and thus on domestic demand and capacity utilization must also be taken into account. If investment decisions are more influenced by capacity utilization than by profits, a stagnation tendency may well set in.

All in all, then, readers can see that both Keynes and Kalecki were very skeptics on the possibility that in open economies a wage-share fall might restore full-employment. Moreover, both of them pointed out the association between wages and the exchange rate, and on this basis Kalecki suggested, though he did not clearly develop the point, that currency depreciation might depress demand.

This last point was, however, clearly formulated by Latin American authors, who explicitly developed the point hinted at by Kalecki. ${ }^{12}$

Indeed, the distributional effect of currency depreciation, anticipated by Kalecki (1939b), was re-discovered a few years later by the Chilean Jorge Ahumada. He argued:

\footnotetext{
11 This is not an unlikely possibility. It may well occur in the short run, owing to what has been labeled the J curve effect.

12 Readers are referred to an interesting paper by Fiszbein (2015).
} 
The immediate consequence of [a] devaluation is the rise in the price of wheat, meat, sugar, tea, coffee (...) and a series of other products that are a substantial part of the workers' spending. (...) In view of the fact that income is so unequally distributed and that, in general, it is low, the loss of income that the devaluation of the exchange rate implies for the wage earners is socially intolerable (...). (AHUMADA, 1958, p. 126-127, our translation)

A few years later, the Argentinian Aldo Ferrer (1963) gave a more complete view of the negative effects on demand of devaluation anticipated by Kalecki. I think the best I can do is to reproduce selected passages from his paper (my own translation):

In the first place, Ferrer called attention to one important peculiarity of Argentina: “[a]bout 95\% of Argentine exports are composed of agricultural products, basically meats, wool, hides, by-products of livestock, cereals and oilseeds" (FERRER, 1963, p. 5) and "the agricultural products exported are of the same nature as those destined for the domestic market to satisfy the food demand of the population and to supply the rural products processing industry" (FERRER, 1963, p. 6).

Ferrer then went on to discuss the effect of devaluation: "[t]he devaluation of the peso has an immediate effect on the general level of prices due, first, to the simultaneous increase in the prices in pesos of exports and, second, due to the increase in the costs of industries that use imported inputs" (FERRER, 1963, p. 12).

Further: "[ $\mathrm{t}]$ he modification of the price structure produced by the devaluation not only generates intersectoral transfers of income, (...) [i]t also alters the distribution of income between the income of workers and that of capital and firms". More precisely, due to the devaluation: "[t]here must necessarily take place a decrease in the share of labor in the income of the economy as a whole" (FERRER, 1963, p. 11).

He then went on:

The contraction of the real income of the working population causes an even greater drop in the demand for non-essential industrial goods, because a growing proportion of real income is absorbed by spending on food and housing. Given the high degree of concentration of most of the industrial production of the country (...) the adjustment of supply to the lower level of demand is made by a reduction in the quantity produced and not by a contraction in prices. (FERRER, 1963, p.12-13)

And finally, "[i]n this way, the devaluation [brings about] the fall of real wages, the contraction of effective demand and the growing unemployment of the installed capacity in industry" (FERRER, 1963, p. 13). 
Of course, Argentina's particular type of exports brought about a rapid and palpable negative effect of devaluation on real wages in that country. This is probably why other researchers studying this country also stressed the effects of devaluation emphasized by Ferrer (see for instance BRAUN and JOY, 1968; and DIAZ ALEJANDRO, 1963).

On my recollection, in the 1960s and 1970s the contraction of effective demand that the wage fall ensuing from a devaluation may entail was "in the air" in the economic debates in Latin America. This is unsurprising: when the first wave of this discussion took place in our continent, most countries exported primary goods with low short-term elasticity of supply and demand and had an industrial sector still relatively undeveloped. Therefore, the positive effect of currency depreciation on the trade balance was rather limited..$^{13}$

But Latin American economists also called attention to an additional effect of currency depreciation. Though Keynes did not explicitly consider this effect, it has much to do with what he considered "the depressing influence on entrepreneurs of their greater burden of debt" ensuing a fall in nominal wages and prices. On this issue, the Argentinian economist Belozercovsky (1970) was, to my knowledge, the first author to call attention to the negative impact that currency depreciation may have on the balance sheets of domestic firms indebted in foreign currency. If such firms are net debtors in foreign currency, devaluation automatically brings about a negative impact on their balance sheets. Of course, Belozercovsky was also much influenced by the conditions of his own country, where large firms used to have recourse to foreign lending, given the limitations and high cost they found in the domestic sources of credit.

\section{THE ECONOMIC POLICY IMPLICATIONS}

To complete the picture, it may be interesting to briefly consider the economic policy conclusions that the 'heretics' inferred from their analysis.

In the first place, in spite of Keynes' rejecting that a wage fall would stimulate demand and employment, he did not advocate a wage rise to stimulate employment. This may have been due to his assumption that the marginal productivity of labor would decline with higher employment, which in turn would require lower wages to

${ }^{13}$ Of course, in the more recent past, the situation has changed spectacularly. Many Latin American countries have achieved considerable progress as exporters of manufacturing goods and developed their manufacturing sector considerably. This is probably why the debate has now reappeared in a different guise. 
stimulate firms to hire more workers. Also, it may have been due to his concern about the profitability and international competitiveness of domestic production.

Wage rise was, however, one of the policy conclusions that Kalecki arrived at from his theoretical reflection. Indeed, income redistribution through wages rising faster than labor productivity was one of the "three ways of full employment" he advocated in the paper he published under this title (KALECKI, 1944a). Many years later, when he took part in a conference at a Polish-Italian workshop held in Ancona in 1965 on 'popular front' policy for countries like France and Italy, one of the measures he supported was price control but not control over wages. Nevertheless, he also warned that excessive wage rises might jeopardize workers' real income due to price rises. ${ }^{14}$ Though Kalecki might be accused today of "populism", to use the currently common parlance, readers should be recalled that the measures he proposed were not seen as too extreme at that time and even later. In fact, important wage rises were implemented during the first year of President Allende's government in Chile. Also, after the 1981 victory, President Mitterrand's left coalition government in France decreed a 10\% rise in the minimum wage. ${ }^{15}$

The 'heretics' I have discussed had also a lot to say about management of the exchange rate and competitiveness. ${ }^{16}$ They certainly recognized the importance of ensuring international competitiveness for any country and thus the need for a competitive exchange rate. Also, they did not reject currency depreciation in all circumstances. However, they were rather skeptics about currency depreciation benefits as the sole or the main instrument for that purpose.

Thus, for example, Keynes argued:

I have no sympathy with the idea, which (...) I regard as vestigial, that, if imports have to be restricted, it is in some way sounder to raise their price by depreciation of the exchanges than by any other techniques". And he added "Surely, the best plan is to have both import restrictions and exchange depreciation at hand, and use each of them in appropriate degree and on approppriate occasions. (KEYNES, 1980, p. 289)

${ }^{14}$ Kalecki's paper at that conference was never published and went lost. My comments on the issue come from the account given by Osiatynsky (1993, p. 182-184) and from Ignacy Sachs's recollection from that conference (personal communication to the present author).

15 To discuss whether or not excessive wage rises contributed to the failure of these two experiences is beyond the scope of the present work.

16 Though this issue is only indirectly related to our discussion on the effect of changes in the wage share on demand and employment, it may be important to have a more complete view of their outlook. 
Kalecki did not explicitly discuss the benefits and problems of currency depreciation. However, in the early 1950s, he was invited to discuss the economic problems of Israel, which faced hardships in its balace of payments. On that occasion, he recommended different solutions from devaluation. In his words:

Considerable excess capacity exists in Israel (...) in such light industries as textiles, apparel, shoes, leather goods, etc. This capacity could be mobilized for exports, provided markets were found for such products abroad (...) However (...) Israel goods of this type are too expensive and require considerable export premiums. It is essential that such premiums be granted, even if they should amount to a relatively high percentage of the value added. Export premiums should nevertheless be kept as low as possible and other inducements should also be used for expanding exports. The allocation of raw materials for production for the home market should be made dependent on the export performance of firms so that they will be encouraged to export at prices lower than those achieved on the home market. (KALECKI, 1993[1951], p. 100)

I will finally give the word to Raul Prebisch. On this subject, the view of the founding father of the Latin American Structuralist School of Economics is especially interesting, because he had a different problem in mind than Keynes and Kalecki. Readers will surely recall that one of Prebisch's basic concerns was with the declining terms of trade that underdeveloped countries confronted in general, and especially when they tried to expand their exports of primary commodities. As a consequence, he considered that industrialization was the only, or at least the most promising route to overcome backwardness. In his words:

the plea for technical advance in primary production as an alternative to industrialization in order to improve standards of living defeats its own purpose, as some of the fruits of such technical advance will usually be transferred from the peripheral countries to the outer world, unless it is buttressed by a vigorous process of industrialization and increasing productivity in industry. The greater the inelasticity of demand for peripheral exports, the larger the proportion of the fruits that is so transferred. (PREBISCH, 1959, p. 252)

And he went on to argue:

Import substitution (defined here as an increase in the proportion of goods that is supplied from domestic sources and not necessarily as a reduction in the ratio of 
imports to total income) is the only way to correct the effects on peripheral growth of disparities in foreign trade elasticity. (PREBISCH, 1959, p. 253)

And he concluded:

I have strong doubts about the advisability of exchange rate adjustments as an instrument to correct foreign trade disparities in demand elasticities. The main appeal of depreciation as compared with protection is that it leaves private initiative rather than government agencies to decide which branches of industry will be profitable substitutes for imports. But this could also be achieved through a uniform protective duty. Protection (or subsidies) seems a more direct and simple solution, as it limits the adjustment to those new branches of industries that should be developed within a given period of time. To obtain the same result, depreciation forces the adjustment of the whole price system. In my view, a policy of depreciation or devaluation should be used only to correct an externally overvalued currency and not as an instrument for effecting structural changes in the economy. A selective protection policy is a preferable instrument, notwithstanding the obstacles that have to be overcome in practice. (PREBISCH, 1959, p. 257)

\section{CODA: A BRIEF REMARK ON EMPIRICAL FINDINGS}

During the lifetime of Keynes, Kalecki and the other relevant authors herein considered, economic debates took place typically on an analytical basis, and participants adduced mostly institutional reasons and logical arguments in favor of their positions. Nowadays, given the larger availability of data and our greater capacity to process it, we are in a better position to test hypotheses. This is very important, because theories cannot be judged solely based on prior considerations.

This is why, in this final section, I will show the results of econometric estimations that I have carried out elsewhere to analyze the association between wages and the exchange rate, on the one hand, and effective demand and output, on the other. ${ }^{17}$ It is a sample of selected countries, and what I present are the long-term equations estimated on the determinants of effective demand and output. In each case, I specified

\footnotetext{
${ }^{17}$ I hope readers will excuse me for showing only results from my own research. But my intention is not going into the contemporaneous debate but only to illustrate with some real data the validity of the hypotheses put forward by the authors discussed here.
} 
general models, which included amongst the selected variables the wage share or the prate or both to test the hypotheses about their effects on the GDP. I will not carry out here a discussion of the equations, and I refer interested readers to the papers from which the results have been taken. ${ }^{18}$

In the following equations Y denotes the country's GDP; $\mathrm{Y}^{*}$ is World GDP; W the wage share in GDP; $q$ is the real exchange rate; $G$ is government expenditure; $M$ is the amount of money (which I have used as a proxy for liquidity); R refers to the real interest rate; and Trend is the trend. In the case of USA, C is credit to the private sector, $\mathrm{H}$ are taxes on profits, and $\mathrm{O}$ are other taxes.

Table 1 - Long run output equations, selected countries

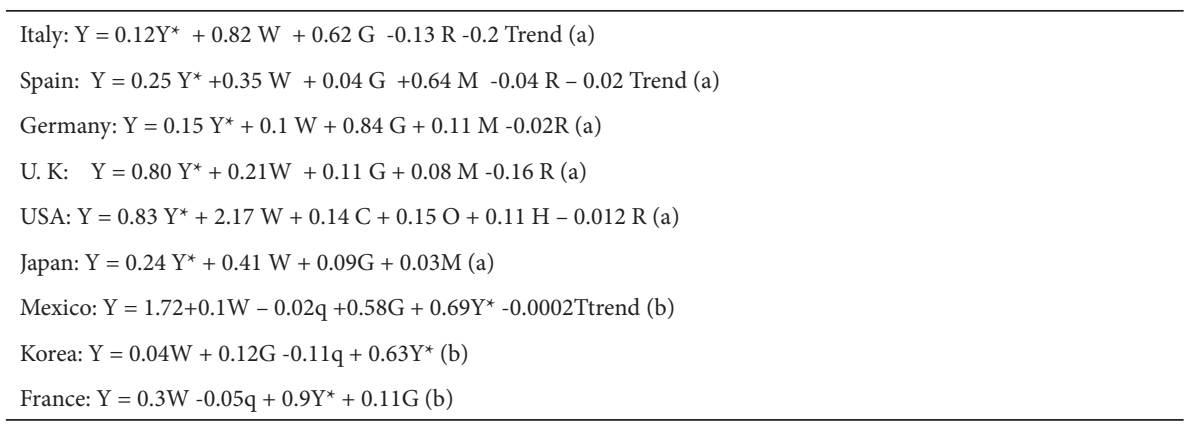

Sources: Author's elaboration based on (a) López (2013) and (b) De Jesús and López (2019).

In words, the cointegration analysis shows the existence of a stable long-run relationship between output and the variables in the right hand-side of the equations. In all the countries that I have been able to study higher output is associated with a higher share of wages in value added, or with a lower real exchange rate, or both.

As I discussed in the papers from which I took the above results, the meaning of the estimated equations is straightforward: if the wage share rises, or if the real exchange rate declines, or both, demand and output will be stimulated. In short, my findings lead me to conclude that the hypotheses formulated more than ahalf a century ago by Kalecki, Keynes, Steindl and the other authors discussed in the present paper appear to be valid.

18 For all countries I followed what Spanos $(1999,2009)$ calls "a probabilistic approach to econometrics". This approach stresses the use of statistically adequate models as the basis of drawing reliable inferences. The term statistically adequate refers to the validity of the probability and the statistical assumptions underlying the estimated model. I estimated Vector Auto Regression (VAR) models for each country and carried out misspecification tests to ensure their statistical validity. Finally I estimated the long-run equilibrium equation for the selected variables (JOHANSEN, 1988). 
Of course, the econometric estimate does not entail that to achieve fast economic growth the best policy would be to simply appreciate the currency, or push up wages. But to discuss the economic policy conclusions of the above findings is beyond the scope of the present paper.

FINAL REMARKS

The effects of changes in wages and the wage-share on economic growth figure in the research agenda of our discipline in a prominent manner. In their seminal paper, Bowles and Boyer (1988) specified a macroeconomic model to formally study this issue and introduced the now fashionable notions of "profit-led" and "wage-led" demand regimes. Another research with the same spirit soon followed - Bhaduri and Marglin (1990) - and inaugurated the contemporary debate. As a result, a large literature on the subject has emerged among followers of Keynes's and Kalecki's ideas.

The first objective of this paper was to reanalyze the growth-distribution nexus from the perspective of the history of economic ideas. In the first place, I reviewed how the seeds were sown for the heretic view that a wage fall may not bring about a return to full employment and in certain cases may increase unemployment. This objective was motivated by a somewhat surprising situation. In the course of the discussion about demand regimes, it seems to have been forgotten that one of Keynes's main purposes in The General Theory was to strongly refute the classic claim that (downward) money-wage flexibility would stimulate demand and ensure full employment. Thus, at least by implication, he rejected the notion that growth could be profit-led. In this context, I also recollected that Michal Kalecki went even further, inasmuch as he argued that a wage fall would deepen unemployment (KALECKI, 1939b). Later on, Josef Steindl further elaborated on Kalecki's vision to construct his long-run stagnation theory. Given the above, I am tempted to add, using here the beautiful expression coined by James Tobin, that now in our camp "[ $\mathrm{t}$ ]he controversy of the 1930s is being replayed today" (TOBIN, 1980, p. 20).

My second objective was to extend the scope of the analysis and to argue that the same line of reasoning can be applied to study the exchange rate-demand nexus. In this context, I considered how the wage share and the real exchange rate relate to each other and I discussed how the notion that currency depreciation may contract demand has emerged. This second topic is seldom considered in the discussion of demand regimes, but I hope to have shown that it has a proper place in the debate. Besides, readers will find out that Latin American economists have much to say about the last point discussed here. 
In the third place, I recollected the economic policy inferences that the authors discussed here had deduced from their analytical reflections. I referred to this issue very briefly because it is a bit beyond the scope of the paper. However, it is useful to have a more complete picture of the implications of the debate about demand regimes.

Readers surely must have noticed that I did not review the debate that immediately followed as the authors I consider here exposed their ideas or the more contemporaneous discussion on this issue. As to the empirical literature assessing what we can learn from the data about whether growth is wage- or profit-led, I simply added a brief Coda to show some results I have found in other works, but without further discussion. ${ }^{19}$ Thus, in the present paper I rather limited myself, so to speak, to an exercise in exegesis. But it is always important to recollect that we latecomers to the economics debate can benefit from an important advantage. We can stand on the shoulders of those giants that preceded us to construct our own vision. This is why we should not forget the lessons that they taught us.

\section{REFERENCES}

AHUMADA, J. En vez de la miseria. Santiago de Chile: Editorial del Pacífico, 1958.

BARBOSA-FILHO, N. H.; TAYLOR, L. Distributive and demand cycles in the US economy: a structuralist Goodwin model. Metroeconomica, v. 57, n. 3, p. 389-411, 2006

BELOZERCOVSKY, N. Devaluación, deuda extranjera y el proceso de ajuste. Económica, v. XVI, n. 1, 1970, pp. 21-29, 1970.

BHADURI, A.; MARGLIN, S. Unemployment and the real wage: economic basis for contesting political ideologies. Cambridge Journal of Economics, v. 14, p. 375-395, 1990.

BOWLES, S.; BOYER, R. Labor discipline and aggregate demand: a macroeconomic model. The American Economic Review, Papers and Proceedings, v. 78, n. 2, p. 395-400, 1988.

BRAUN, O.; LEONARD, J. A model of economic stagnation. A case study of the Argentine economy. Economic Journal, v. 78, n. 312, p. 868-887, 1968.

CABALLERO, E.; LÓPEZ G., J. Fiscal policy and private investment in Mexico. In: ARESTIS, P. (Ed.) Microeconomics, macroeconomics and economic policy: essays in honour of Malcolm Sawyer. London: Palgrave Macmillan, 2011, p. 218-227.

CABALlERO, E.; LÓPEZ G., J. Demanda efectiva y distribución del ingreso en la evolución reciente de la economía mexicana. Investigación Económica, v. 72, n. 285, p. 141-163, 2013.

19 On these issues readers are referred to López (2003), Caballero and López (2011 and 2013), and Lopez, Sanchez and Spanos (2011), De Jesús and López (2019) and the literature cited therein. 
CARVALHO, F. C.; LÓPEZ G., J. Learning from the past: two stories of successful state intervention in capitalism. In: ROSSELLI, A.; SANFILIPPO, E.; NALDI, N. (Eds.) Money, finance and crises in economic history. The long-term impact of economic ideas. Essays in Honour of Maria Cristina Marcuzzo. London: Routledge, 2019.

DE JESÚS, V.; LÓPEZ G., J. On wage- and profit-led demand regimes: learning from the evidence. Journal of Post Keynesian Economics, v. 42, n. 4, p. 620-637, 2019. DOI: $10.1080 / 01603477.2019 .1672562$

DÍAZ ALEJANDRO, C. A note on the impact of devaluation and the redistributive effect. Journal of Political Economy, v. 71, n. 6, p. 577-5, 1963.

FEI, J. C. H.; RANIS, G. A theory of economic development. The American Economic Review, v. 51, p. 533-565, 1961.

FERRER, A. Devaluación, redistribución ingresos y el proceso de desarticulación industrial en la Argentina. Desarrollo Económico, v. 2, n. 4, p. 5-18, 1963.

FISZBEIN, M. La economía del stop and go: las ideas estructuralistas en Argentina, 1945-1976. Desarrollo Económico, v. 55, n. 216, p. 187-210, 2015.

GOODWIN, R. M. A growth cycle. In: FEINSTEIN, C. H. (Ed.) Socialism, capitalism and economic growth. Cambridge: Cambridge University Press, 1967, p. 54-58.

GURRIERI, A. (Ed.) La obra de Prebisch en la CEPAL. México: Fondo de Cultura Económica, 1982.

HICKS, J. R. Mr. Keynes and the "Classics": a suggested interpretation. Econometrica, V. 5, p. 147-59, April, 1937.

KALECKI, M. Three systems. In: OSIATYNSKY, J. (Ed.) Collected works of Michael Kalecki. Oxford: Oxford University Press, 1934[1990]. v. 1.

KALECKI, M. Essays in the theory of economic fluctuations. In: OSIATYNSKY, J. (Ed.) Collected works of Michael Kalecki. Oxford: Oxford University Press, 1939a[1991]. v. 1.

KALECKI, M. Money and real wages In: OSIATYNSKY, J. (Ed.) Collected works of Michael Kalecki. Oxford: Oxford University Press, 1939b[1991]. v. 2.

KALECKI, M. Three ways to full employment. In: OSIATYNSKY, J. (Ed.) Collected works of Michael Kalecki. Oxford: Oxford University Press, 1944a[1990]. v. 1.

KALECKI, M. Professor Pigou on 'The Classical Stationary State.' In: OSIATYNSKY, J. (Ed.) Collected works of Michael Kalecki. Oxford: Oxford University Press, 1944b[1990], p. 342-3. v. 1.

KALECKI, M. The problem of financing economic development. In: OSIATYNSKY, J. (Ed.). Collected works of Michal Kalecki. Oxford: Oxford University Press, 1954 [1993]. v. 5.

KALECKI, M. Class struggle and the distribution of national income. In: OSIATYNSKY, J. (Ed.) Collected orks of Michael Kalecki. Oxford: Oxford University Press, 1971[1991]. v. 2.

KEYNES, J. M. The collected writings of John Maynard Keynes. London: Macmillan, 1980. v. 26.

KEYNES, J. M. The general theory of employment, interest and money. New York: Harcourt Brace \& Company, 1964.

KEYNES, J. M. Relative movements of real wages and output. Economic Journal, v. 49, n. 143, p. 34-51, 1939. 
KEYNES, J. M. A treatise on money. London: Macmillan, 1930. v. 1 e 2.

LEWIS, W. A. Economic development with unlimited supplies of labour. The Manchester School, v. 22, p. 139-91, 1954.

LÓPEZ G., J. Keynes, Kalecki, and the real world. In: HIRAI, T.; MARCUZZO, M. C.; MEHRLING, P. Keynesian reflections. Effective demand, money, finance and policies in the crisis. Oxford: Oxford University Press, 2013.

LÓPEZ G., J.; ASSOUS, M. Michael Kalecki. London: Palgrave-Macmillan, 2010.

LÓPEZ G., J.; SÁNCHEZ, A.; SPANOS, A. Macroeconomic linkages in Mexico. Metroeconómica, v. 62, n. 2, p. 356-385, 2011.

MINSKY, H. P. Stabilizing an unstable economy. London: Yale University Press, 1986.

MINSKY, H. John Maynard Keynes. New York: Columbia University Press, 1975.

OSIATYNSKY, J. (Ed.) Collected works of Michal Kalecki. Oxford: Oxford University Press, 1993. v. 5.

PALAZZI, M. (Ed.) Intervista a un economista: Richard Goodwin. Con la bibliografia degli scritti. Bologna: Editrice CLUEB, 1982.

PREBISCH, R. Commercial policy in the underdeveloped countries. American Economic Review, v. 49, p. 251-273, 1959.

STEINDL, J. Maturity and stagnation in American capitalism. Oxford: Blackwell, 1952.

TOBIN, J. Asset accumulation and economic activity. Chicago: University of Chicago Press, and Oxford: Blackwell, 1980. 